\title{
ТЕНДЕНЦИИ ОПТИМИЗАЦИИ СОСТАВОВ МОДИФИКАТОРОВ MgLaFeSi ДЛЯ ЭФФЕКТИВНОГО ПРОИЗВОДСТВА ЧШГ КОВШОВЫМИ СПОСОБАМИ
}

\author{
Э.В. Захарченко, Е.А. Сиренко, Н.Ф. Зубенина, А.В. Богдан
}

Физико-технологический институт металлов и сплавов НАН Украины, г. Киев, Украина

Лантан содержащие комплексные модификаторы MgLaFeSi используются в производстве чугуна с шаровидным графитом (ЧШГ) в течение 40 лет. Сначала исключительно для процессов «in-mold», a затем в последние 12 лет его стали чаще использовать для обработки в ковшах. Эти сплавы приобрели популярность по нескольким причинам, таким как: уменьшение усадки, улучшение микроструктурных свойств и более низкий уровень лантана в сплаве по сравнению с общим уровнем редкоземельных элементов (РЗМ) в сплавах на основе мишметалла. В последнее время это превратилось в заметное экономическое преимущество для магний-лантанферросилициевых лигатур $[1,2]$.

В 2004 году доклад доктора Т.Скаланда «Новый метод контроля отбела и усадки ЧШГ, полученного ковшовой обработкой», был представлен на Всемирном конгрессе литейщиков, получив награду за лучшую статью. В докладе было показано, что модификаторы MgLaFeSi имеют гораздо более широкое применение, чем в процессе ин-молд. За последние 12 лет модификатор на основе лантана MgLaFeSi превратился из узкоцелевого продукта в сфероидизатор массового производства более 1,5 млн. тонн отливок из ЧВГ, исходя из текущих рыночных данных.

Первое использование лантана в качестве единственного источника P3M в MgFeSi восходит к ранним годам процесса 
формовки, когда тенденция к уменьшению усадки была продемонстрирована с помощью чистого $\mathrm{LaMgFeSi}$ без использования других РЗМ [3]. Выпуск этих модификаторов увеличил свою долю рынка благодаря успеху за счет уменьшения усадки улучшения механических свойств и улучшения качества механической обработки поверхности отливок. Выяснилась устойчивая тенденция сокращения и устранения усадки. Использование лантана, как было установлено, усиливает выделение включений графита на поздних стадиях затвердевания ЧШГ, добавляя эффект позднего расширения для уменьшения усадочной пористости.

Первоначальная работа по разработке проводилась при расходе MgLaFeSi 1,5\% (масс.) и вводе в состав MgFeSi 0,5\% лантана. Среднее количество добавки $\mathrm{MgFeSi}$ в ковшовой практике в настоящее время оценивается примерно в 1,2\%.

Обсуждаются результаты исследований концентрации La в $\mathrm{MgFeSi}$ и влияния на количество графитовых включений. Наибольшее количество зародышей было обнаружено при $0,5 \%$ $\mathrm{La}$ в $\mathrm{MgFeSi}$, причем более низкое зародышеобразование наблюдалось как при более высоких, так и при более низких уровнях лантана.

Следует быть осторожнее при использовании одного и того же уровня для любого процесса. Учитывая важность лантана в уравновешивании вредных элементов, следует принимать во внимание качество исходного расплава чугуна. Для применения лантана должен быть рассчитан стехиометрический баланс, который можно оценить как РЗМ / SubversiveElements = 0.5. (Sub.Elem. = Pb, As, Bi и Sb). Общая концентрация $\mathrm{Pb}, \mathrm{As}, \mathrm{Bi}, \mathrm{Sb}$ 0,008 потребовала бы добавления лантана 0,004\%.

Вывод: При переходе с MgFeSi на основе РЗМ лучше не компенсировать снижение количества РЗМ на основе лантана. При наличии уровней содержания лантана в сплаве выше оптимального, многие из наблюдаемых преимуществ, 
касающихся усадки и структуры, будут уменьшены, в дополнение к повышению стоимости сплава.

\section{Литература}

1. 46th Census of World Casting Production - Modern Casting, December 2012. - P. 26-29

2. Рябчиков И.В., Панов А.Г., Корниенко А.Э. О качественных характеристиках модификаторов. 2007, Сталь №6. - С. 18-23.

3. Захарченко Э.В., Левченко Ю.Н., Горенко В.Г., Вареник П.А. Отливки из чугуна с шаровидным и вермикулярным графитом. 1986. Киев: Наук. думка,. -248 с. 